\title{
REVISED Anti-hypercholesterolemic effect of Zingiber montanum
}

\section{extract [version 2; peer review: 2 approved]}

\author{
Swandari Paramita(iD1,2, Meiliati Aminyoto1,2, Sjarif Ismail1,3, Enos Tangke Arung 4 \\ ${ }^{1}$ Research Center for Medicine and Cosmetics from Tropical Rainforest Resources, Mulawarman University, Samarinda, East \\ Kalimantan, 75119, Indonesia \\ ${ }^{2}$ Laboratory of Community Medicine, Faculty of Medicine, Mulawarman University, Samarinda, East Kalimantan, 75119, Indonesia \\ ${ }^{3}$ Laboratory of Pharmacology, Faculty of Medicine, Mulawarman University, Samarinda, East Kalimantan, 75119, Indonesia \\ ${ }^{4}$ Laboratory of Forest Product Chemistry, Faculty of Forestry, Mulawarman University, Samarinda, East Kalimantan, 75119 , \\ Indonesia
}

V2 First published: 15 Nov 2018, 7:1798

https://doi.org/10.12688/f1000research.16417.1

Latest published: 14 Aug 2019, 7:1798

https://doi.org/10.12688/f1000research.16417.2

\section{Abstract}

Background: High cholesterol levels (hypercholesterolemia) has been recognized to cause various disease, most notably the cardiovascular disease. Unfortunately, most anti-hypercholesterolemic drugs deliver several side effects for patients, by which medicinal plants have begun to attract attention for treating hypercholesterolemia. Among others, Zingiber montanum (J.König) Link ex A.Dietr. has traditionally been taken for treating health problems caused by high cholesterol levels. Hence, this work aimed at investigating anti-hypercholesterolemic effects offered by the plant.

Methods: This study was conducted on 30 male Wistar rats. During experiments, the subjects were divided into 6 groups $(n=5)$, i.e. no treatment (Group 1, control); high-fat diet (Group 2, control); high-fat diet with simvastatin (Group 3); high-fat diet with plant extracts (Group 4-6 with 100, 200, and $400 \mathrm{mg} / \mathrm{kg} \mathrm{BW,} \mathrm{respectively).} \mathrm{After} 4$ weeks of treatments, blood samples were collected from each group. Then, plasma concentrations of triglycerides, total cholesterol, high density lipoproteins (HDL), and low density lipoproteins (LDL) were measured.

Results: There were significant differences in total cholesterol $(p=0.000), \operatorname{LDL}(p=0.000)$ and triglycerides $(p=0.001)$ for Groups 4-6 (high-fat diet treated with different plant extract doses) in comparison with Group 2 (high-fat diet, control). Meanwhile, there were no significant differences in HDL levels $(p=0.830)$ between Group 2 (highfat diet, control) and other groups. The results also showed significant differences in total cholesterol and LDL for subjects treated with plant extracts (Group 4, 100 mg/kg BW, p=0.000; Group 5, 200 mg/kg BW, $\mathrm{p}=0.000$; Group 6, $400 \mathrm{mg} / \mathrm{kg} \mathrm{BW,} \mathrm{p}=0.000$ ) compared to Group 2 (high-fat diet, control). Then, treatments with 400 mg/kg BW (Group 6) discovered significant reductions in total cholesterol, LDL, and triglycerides $(p=0.030)$.

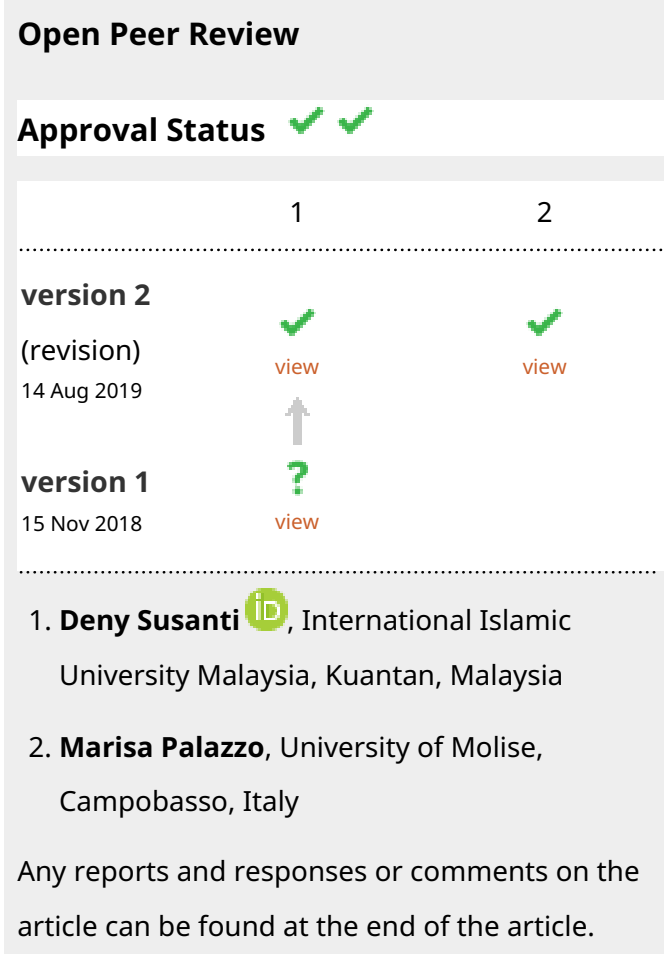


Conclusion: Therefore, Z. montanum has been discovered to deliver anti-hypercholesterolemic effects to experimental subjects, making it potential to act as a natural source of anti-hypercholesterolemic agents.

Keywords

anti-hypercholesterolemic, Zingiber montanum

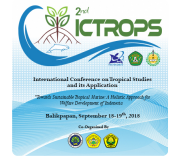

This article is included in the ICTROPS 2018

collection.

Corresponding author: Enos Tangke Arung (tangkearung@yahoo.com)

Author roles: Paramita S: Conceptualization, Project Administration, Supervision, Writing - Original Draft Preparation; Aminyoto M: Data Curation, Software, Writing - Review \& Editing; Ismail S: Formal Analysis, Methodology, Visualization; Arung ET: Funding Acquisition, Investigation, Resources, Validation

Competing interests: No competing interests were disclosed.

Grant information: This work was supported with funding from the Project Implementation Unit IsDB Universitas Mulawarman for financing this research, as part of the implementation of IsDB Grant Research Year of 2018 [448/UN17.45/DL/2018].

The funders had no role in study design, data collection and analysis, decision to publish, or preparation of the manuscript.

Copyright: (c) 2019 Paramita S et al. This is an open access article distributed under the terms of the Creative Commons Attribution License, which permits unrestricted use, distribution, and reproduction in any medium, provided the original work is properly cited.

How to cite this article: Paramita S, Aminyoto M, Ismail S and Arung ET. Anti-hypercholesterolemic effect of Zingiber montanum extract [version 2; peer review: 2 approved] F1000Research 2019, 7:1798 https://doi.org/10.12688/f1000research.16417.2

First published: 15 Nov 2018, 7:1798 https://doi.org/10.12688/f1000research.16417.1 


\section{REVISED Amendments from Version 1}

1. The plant was authenticated by Ir. Hj. Hastaniah, M.P. and the voucher specimen (voucher number: 27b/UN17.4.3.08/ LL/2018) was deposited to the Laboratory of Dendrology and Forest Ecology, Faculty of Forestry, Mulawarman University, Samarinda, Indonesia.

2. One replication was conducted in each experiment of every sample.

3. The discussion has been rewritten to explain the results of the experiments, and compare with previous research to support the results.

4. All the species names have been corrected to "Zingiber montanum" for the first, and "Z. montanum" for the subsequent.

5. Due to the inauguration of a new name for our research institution, affiliation 1 has been amended to say "Research Center for Medicine and Cosmetics from Tropical Rainforest Resources".

Any further responses from the reviewers can be found at the end of the article

\section{Introduction}

Hypercholesterolemia is a health condition characterized by a very high level of cholesterol in the blood ${ }^{1}$. If it is not well treated, hypercholesterolemia certainly increases coronary heart disease risk ${ }^{2}$. In current advances, various agents have been made available to treat hypercholesterolemia patients, including HMG CoA reductase inhibitors or statins (i.e. Simvastatin) $)^{3,4}$.

To avoid unintended side effects of artificially made antihypercholesterolemic agents, medicinal plants have begun to attract attention for treating hypercholesterolemia. In Indonesia, various locally growing plants have been used for traditional medicine. Among others, Zingiber montanum (J.König) Link ex A.Dietr., which belongs to the family Zingiberaceae, has been recognized to act as a traditional medicine in East Kalimantan, Indonesia, for treating health problems caused by high cholesterol levels ${ }^{5-8}$. This study, therefore, aimed at investigating anti-hypercholesterolemic effect of Z. montanum.

\section{Methods}

\section{Plant material}

The sampling of $Z$. montanum was conducted in the Kutai Kartanegara, East Kalimantan, Indonesia (0²4'18.4”S $\left.117^{\circ} 4^{\prime} 24.7^{\prime \prime} \mathrm{E}\right)$. The plant was carefully verified by Ir. Hj. Hastaniah, M.P. to ensure its authenticity. The voucher specimen (voucher no. 27b/UN17.4.3.08/LL/2018) was then deposited in the Laboratory of Dendrology and Forest Ecology, Faculty of Forestry, Mulawarman University, Indonesia.

\section{Plant extraction}

In the laboratory, the rhizomes of Z. montanum were sliced and dried at room temperature for 3 days. After that, they were crushed and transferred into a glass container. Crushed rhizomes was soaked in absolute ethanol (9401-03 Alcohol, Anhydrous, Reagent, J.T. Baker) for 5 days. The mixture was shaken occasionally with a shaker (3525 Incubator Orbital Shaker, Lab-Line, US). After 5 days, it was filtered (Whatman Filter Paper $11 \mu \mathrm{m}$, Sigma-Aldrich) and evaporated by using a rotary evaporator
(RV06-ML Rotary Evaporator, IKA, Germany). In the end, dried extracts were obtained and stored at $4^{\circ} \mathrm{C}$ in a dark bottle.

\section{Experimental model}

In this study, experiments were designed to follow Federer's rule, with six groups of induction. For the experiments, 30 male Wistar rats (Rattus norvegicus, weighing 250-350g, aged 12-13 months) were obtained from Animal House of the Faculty of Medicine, Mulawarman University, Indonesia. They were randomly divided into 6 groups, i.e. Group 1 (no treatment, control), Group 2 (high fat diet, control), Group 3 (high fat diet with simvastatin), and Groups 4-6 (high fat diet with separate doses of Z. montanum extract; 100, 200, and $400 \mathrm{mg} / \mathrm{kg}$, respectively). They were acclimatized for one week in a controlled room temperature $\left(25^{\circ} \mathrm{C}\right)$ with a 12-hour light/dark cycle. Besides, they were provided with an access to food pellets, while filtered water was provided ad libitum to help them adapt to the new environment. During experiments, each test subject was separately housed in a wire cage $(30 \times 30 \times 30 \mathrm{~cm})$. In all treatments, high-fat diets were administered for all test subjects for 4 weeks, in which $10 \%$ chicken egg yolk and reused cooking oil were added to their standard pellet diets (JAPFA, Comfeed, Indonesia) with tap water ad libitum.

\section{Biochemical analysis}

After 4 weeks of treatment, blood samples were collected from each treatment group separately after an overnight fasting. All test subjects were anesthetized intraperitoneally with a ketamine injection (Hameln, Germany) at a $60 \mathrm{mg} / \mathrm{kg}$ BW dose before taking the blood samples. After the anesthetize, each test subjects was euthanized by applying cervical dislocation. Each blood sample was aspirated through the left ventricle of test subject's heart. Practically, two millilitres of blood were aspirated by using a $3 \mathrm{ml}$ disposable syringe to later be filled into a vaccutainer tube with an anticoagulant. Then, plasma concentrations of triglycerides, total cholesterol, high density lipoproteins (HDLs), and low density lipoproteins (LDLs) were measured in three repetitions for each sample by utilizing an automatic analyzer system (BiOLis 24i; Boeki, Tokyo, Japan).

\section{Data analysis}

In this work, statistical analyses were performed in SPSS software version 16.0. Data normality was examined by applying the Shapiro-Wilk normality test. Then, parameter data were analyzed by using ANOVA and post hoc with Tukey test. The analyses set $p$-value of $\leq 0.05$ as being significant.

\section{Ethical considerations}

All protocols taken in this study had been approved for Ethical Animal Care from the Medical and Health Research Ethics Commission, Faculty of Medicine, Mulawarman University with approval no. 81/KEPK-FK/V/2018. All possible efforts had been ensured to ameliorate any suffering of animals treated as test subjects in this research.

\section{Results}

Looking at results of the statistical analyses, significant differences were found between total cholesterol $(p=0.000)$, LDL $(\mathrm{p}=0.000)$ and triglycerides $(\mathrm{p}=0.001)$ (Figure 1) levels 
achieved between Group 2 (high-fat diet, control) and Group 4-6 (treatments of $Z$. montanum extracts at different doses). Besides, there was no significant difference in HDL $(\mathrm{p}=0.830)$ levels between Group 2 and other groups. Meanwhile, post-hoc Tukey test revealed significant differences between total cholesterol $(\mathrm{p}=0.000)$ and LDL $(\mathrm{p}=0.000)$ levels of all Z. montanum treatments (Groups 4-6) with the high-fat diet control (Group 2). Then, results for Z. montanum treatment at $400 \mathrm{mg} / \mathrm{kg}$ BW doses (Group 6) particularly discovered significant reductions in total cholesterol, LDL and triglycerides $(\mathrm{p}=0.030)$ (Table 1).

Dataset 1. Effect of ethanol extract of Z. montanum and simvastatin in total cholesterol, triglycerides, high density lipoproteins (HDL), and low density lipoproteins (LDL) levels after 4 weeks of treatment in a high fat diet rat model

\section{https://dx.doi.org/10.5256/f1000research.16417.d221668}

\section{Discussion}

The Z. montanum (Supplementary File 1) has been widely taken as a medicinal plant in Asia. Pharmacological properties of Z. montanum include antimicrobial, antioxidant, insecticidal, anti-cancer, anticholinesterase, and anti-inflammatory ${ }^{9-11}$. In the literature, previous researches on anti-hypercholesterolemic effects of other Zingiber species mainly focused on Z. officinale (a.k.a. ginger $)^{18}$. In general, a restoration of changes in lowdensity lipoprotein and HMG CoA reductase by $Z$. officinale administration with a high-fat diet has been suggested as an explanation for the effect of ginger in hyperlipidemia treatments ${ }^{19}$.

In fact, the rhizome extracts of Z. montanum showed the highest total curcuminoid content compared to other Zingiber species $^{7,12}$. Curcumin as antioxidants would hence be able to efficiently prevent LDL oxidations ${ }^{15}$. The significant changes in LDL levels suggested Z. montanum to deliver an

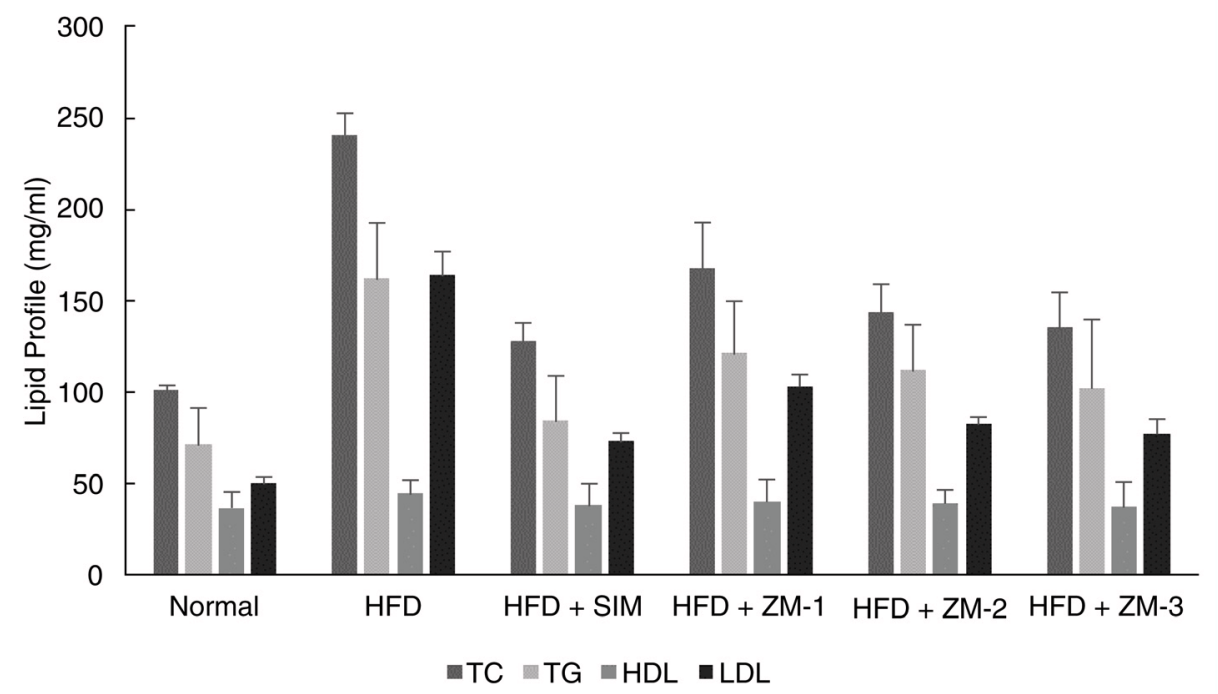

Figure 1. Comparative effect of Z. montanum and simvastatin in total cholesterol (TC), triglycerides (TG), high density lipoproteins (HDL), and low density lipoproteins (LDL) level.

Table 1. Effect of Z. montanum and simvastatin total cholesterol, triglycerides, high density lipoproteins (HDL), and low density lipoproteins (LDL) level.

\begin{tabular}{|l|l|l|l|l|}
\hline Group & $\begin{array}{l}\text { Total Cholesterol } \\
(\mathbf{m g} / \mathbf{m l})\end{array}$ & $\begin{array}{l}\text { HDL } \\
(\mathbf{m g} / \mathbf{m l})\end{array}$ & $\begin{array}{l}\text { LDL } \\
(\mathbf{m g} / \mathbf{m l})\end{array}$ & $\begin{array}{l}\text { Triglycerides } \\
(\mathbf{m g} / \mathbf{m l})\end{array}$ \\
\hline HFD control & $241.0 \pm 11.6$ & $44.8 \pm 6.7$ & $163.8 \pm 13.1$ & $161.8 \pm 30.6$ \\
\hline HFD + SIM & $128.2 \pm 9.4^{*}$ & $38.2 \pm 11.8$ & $73.2 \pm 4.7^{*}$ & $84.2 \pm 24.6^{*}$ \\
\hline HFD + ZM-1 & $168.0 \pm 25.4^{*}$ & $40.6 \pm 11.2$ & $103.1 \pm 6.9^{*}$ & $121.4 \pm 28.4$ \\
\hline HFD + ZM-2 & $144.2 \pm 14.9^{*}$ & $39.2 \pm 6.7$ & $82.6 \pm 3.4^{*}$ & $112.0 \pm 25.0$ \\
\hline HFD + ZM-3 & $135.2 \pm 19.0^{*}$ & $37.2 \pm 14.1$ & $77.5 \pm 7.7^{\star}$ & $102.6 \pm 37.1^{*}$ \\
\hline Normal control & $101.4 \pm 2.2^{*}$ & $36.8 \pm 8.4$ & $50.3 \pm 3.3^{*}$ & $71.4 \pm 19.7^{*}$ \\
\hline
\end{tabular}

Note: HFD = high-fat diet, SIM = simvastatin; ZM-1 = Z. montanum $100 \mathrm{mg} / \mathrm{kg}$;

ZM-2 = Z. montanum $200 \mathrm{mg} / \mathrm{kg} ; \mathrm{ZM}-3=$ Z. montanum $400 \mathrm{mg} / \mathrm{kg}$

${ }^{*}$ Tukey post-hoc test significant $p<0.05$ compared to HFD control 
effect on lipid metabolism ${ }^{16}$. Curcumin with other chemical compounds from $Z$. montanum was then suggested to offer antihypercholesterolemic effects.

\section{Conclusion}

Looking at all results in this study, Z. montanum extract have been discovered to reduce lipid profile levels. The medicinal plant could therefore deliver anti-hypercholesterolemic effects to experimental subjects, making it potential to act as a natural source of the anti-hypercholesterolemic agents.

\section{Data availability}

F1000Research: Dataset 1. Effect of ethanol extract of Z. montanum and simvastatin in total cholesterol, triglycerides, high density lipoproteins (HDL), and low density lipoproteins (LDL) levels after 4 weeks of treatment in a high fat diet rat model., http://dx.doi.org/10.5256/f1000research.16417. d221668 17

\section{Grant information}

This work was supported with funding from the Project Implementation Unit IsDB Universitas Mulawarman for financing this research, as part of the implementation of IsDB Grant Research Year of 2018 [448/UN17.45/DL/2018].

The funders had no role in study design, data collection and analysis, decision to publish, or preparation of the manuscript.

\section{Supplementary material}

Supplementary File 1: Picture of rhizome of Zingiber montanum (J.Koenig) Link ex A.Dietr.

Click here to access the data

1. World Health Organization: Raised Cholesterol: Situation and Trends. Global Health Observatory Data (GHO), 2018. Reference Source

2. National Institutes of Health: Hypercholesterolemia. National Library of Medicine. 2018

Reference Source

3. Libby P: The Pathogenesis, Prevention, and Treatment of Atherosclerosis In Harrison's Principles of Internal Medicine, Nineteenth, DL Kasper, SL Hauser, JL Jameson, AS Fauci, DL Longo, and J Loscalzo, Eds. New York: McGraw-Hill Education, 2015; 291e1-291e10.

Reference Source

4. Draznin B, Epstein S, Turner HE, et al.: Lipids and Hyperlipidemia. In Oxford American Handbook of Endocrinology and Diabetes. New York: Oxford University Press, 2011; 677-687.

5. Iswantini D, Silitonga RF, Martatilofa E, et al:: Zingiber cassumunar, Guazuma ulmifolia, and Murraya paniculata Extracts as Antiobesity: In Vitro Inhibitory Effect on Pancreatic Lipase Activity. HAYATI J Biosci. 2011; 18(1): 6-10. Publisher Full Text

6. The Plant List: Zingiber montanum (J.Koenig) Link ex A.Dietr. 2018; [Online] Reference Source

7. Kantayos V, Paisooksantivatana Y: Antioxidant Activity and Selected Chemical Components of 10 Zingiber spp. in Thailand. J Dev Sustain Agric. 2012; 7(1): 89-96. Publisher Full Text

8. Kementerian Kesehatan RI: Laporan Nasional RISTOJA 2015. Jakarta, Indonesia: Lembaga Penerbit Badan Penelitian dan Pengembangan Kesehatan, 2016. Reference Source

9. Kamazeri TS, Samah OA, Taher M, et al:: Antimicrobial activity and essential oils of Curcuma aeruginosa, Curcuma mangga, and Zingiber cassumunar from Malaysia. Asian Pac J Trop Med. 2012; 5(3): 202-209. PubMed Abstract | Publisher Full Text

10. Buiyan MNI, Chowdhury JU, Begum J: Volatile constituents of essential oils isolated from leaf and rhizome of Zingiber cassumunar Roxb. Bangladesh $J$ Pharmacol. 2008; 3(2): 69-37.

Publisher Full Tex

11. Singh C, Manglembi N, Swapana N, et al.: Ethnobotany, Phytochemistry and
Pharmacology of Zingiber cassumunar Roxb. (Zingiberaceae). J Pharmacogn Phytochem. 2015; 4(1): 1-6. Reference Source

12. Bua-in S, Paisooksantivatana Y: Essential Oil and Antioxidant Activity of Cassumunar Ginger (Zingiberaceae: Zingiber montanum (Koenig) Link ex Dietr.) Collected from Various Parts of Thailand. Kasetsart J (Nat Sci.). 2009; 43 : 467-475. Reference Source

13. Chairul C, Praptiwi P, Chairul SM: Phagocytosis Effectivity Test of Phenylbutenoid Compounds Isolated from Bangle (Zingiber cassumunar Roxb.) Rhizome. Biodiversitas. 2009; 10(1): 40-43. Publisher Full Text

14. Bei WJ, Guo J, Wu HY, et al:: Lipid-regulating effect of traditional chinese medicine: mechanisms of actions. Evid Based Complement Alternat Med. 2012; 2012: 970635 .

PubMed Abstract | Publisher Full Text | Free Full Text

15. Kajal A, Kishore L, Kaur N, et al:: Therapeutic agents for the management of atherosclerosis from herbal sources. Beni-Suef Univ J Basic Appl Sci. 2016; 5(2): 156-169. Publisher Full Text

16. Arthur FKN, Woode E, Terlabi EO, et al.: Evaluation of acute and subchronic toxicity of Annona Muricata (Linn.) aqueous extract in animals. Euro J Exp Bio. 2011; 1(4): 115-124. Reference Source

17. Paramita S, Aminyoto M, Ismail S, et al.: Dataset 1 in: Anti-hypercholesterolemic effect of Zingiber montanum. extract. F1000Research. 2018 http://www.doi.org/10.5256/f1000research.16417.d221668

18. EIRokh el-SM, Yassin NA, El-Shenawy SM, et al.: Antihypercholesterolaemic effect of ginger rhizome (Zingiber officinale) in rats. Inflammopharmacology. 2010; 18(6): 309-315. PubMed Abstract | Publisher Full Text

19. Nammi S, Kim MS, Gavande NS, et al.: Regulation of low-density lipoprotein receptor and 3-hydroxy-3-methylglutaryl coenzyme A reductase expression by Zingiber officinale in the liver of high-fat diet-fed rats. Basic Clin Pharmacol Toxicol. 2010; 106(5): 389-395. PubMed Abstract | Publisher Full Text 


\section{Open Peer Review}

\section{Current Peer Review Status:}

\section{Version 2}

Reviewer Report 16 June 2021

https://doi.org/10.5256/f1000research.22195.r84491

(C) 2021 Palazzo M. This is an open access peer review report distributed under the terms of the Creative Commons Attribution License, which permits unrestricted use, distribution, and reproduction in any medium, provided the original work is properly cited.

\section{Marisa Palazzo}

Department of Agricultural, Environmental and Food Sciences, University of Molise, Campobasso, 86100 , Italy

The purpose of the article was to present the influence of Zingiber montanum on cholesterolemia. The document presents information on the beneficial effect of this spice on the lipid structure of an individual and, therefore, on how it is important to use Z. montanum.

Paper is well written and the experimental design is set up well . However, it is not the first study that is done on the beneficial characteristics of $Z$. montanum and statistical analysis should be better described.

However, I agree that Z. montanum has been discovered to deliver anti-hypercholesterolemic effects to experimental subjects, making it a potential to act as a natural source of antihypercholesterolemic agents.

Before being indexed, the article requires an English language edit.

Is the work clearly and accurately presented and does it cite the current literature? Yes

Is the study design appropriate and is the work technically sound? Yes

Are sufficient details of methods and analysis provided to allow replication by others? Yes

If applicable, is the statistical analysis and its interpretation appropriate? Partly

Are all the source data underlying the results available to ensure full reproducibility? 
Yes

Are the conclusions drawn adequately supported by the results?

Yes

Competing Interests: No competing interests were disclosed.

Reviewer Expertise: Animal production

I confirm that I have read this submission and believe that I have an appropriate level of expertise to confirm that it is of an acceptable scientific standard.

Reviewer Report 22 August 2019

https://doi.org/10.5256/f1000research.22195.r52479

(C) 2019 Susanti D. This is an open access peer review report distributed under the terms of the Creative Commons Attribution License, which permits unrestricted use, distribution, and reproduction in any medium, provided the original work is properly cited.

\section{Deny Susanti}

Department of Chemistry, Faculty of Science, International Islamic University Malaysia, Kuantan, Malaysia

The authors have followed all suggestion given

Is the work clearly and accurately presented and does it cite the current literature? Yes

Is the study design appropriate and is the work technically sound?

Yes

Are sufficient details of methods and analysis provided to allow replication by others? Yes

If applicable, is the statistical analysis and its interpretation appropriate?

Yes

Are all the source data underlying the results available to ensure full reproducibility? Yes

Are the conclusions drawn adequately supported by the results? Yes

Competing Interests: No competing interests were disclosed. 
Reviewer Expertise: Natural Product Chemistry, Bioactivity study

I confirm that I have read this submission and believe that I have an appropriate level of expertise to confirm that it is of an acceptable scientific standard.

\section{Version 1}

Reviewer Report 28 November 2018

\section{https://doi.org/10.5256/f1000research.17936.r40719}

(C) 2018 Susanti D. This is an open access peer review report distributed under the terms of the Creative Commons Attribution License, which permits unrestricted use, distribution, and reproduction in any medium, provided the original work is properly cited.

\section{Deny Susanti}

Department of Chemistry, Faculty of Science, International Islamic University Malaysia, Kuantan, Malaysia

1. The manuscript needs to be sent for proofreading. There are a lot of grammatical mistakes and poor sentence construction, and there is no connection between sentences in paragraphs.

2. In the manuscript, the voucher of herbarium specimen of the plant should be stated, and also where the herbarium specimen is deposited and who is identifying the plant (botanist).

3. Please mention the replication that was conducted in each experiment.

4. Discussion: rewrite the discussion to discuss more details about the results of the experiments and compare the previous research or facts from the article or book, to support the results.

5. Check on how to write the species name of plants for the first and subsequent usage, and be consistent.

Is the work clearly and accurately presented and does it cite the current literature? Yes

Is the study design appropriate and is the work technically sound? Yes

Are sufficient details of methods and analysis provided to allow replication by others? Yes

If applicable, is the statistical analysis and its interpretation appropriate? Yes 
Are all the source data underlying the results available to ensure full reproducibility? Yes

Are the conclusions drawn adequately supported by the results?

Yes

Competing Interests: No competing interests were disclosed.

Reviewer Expertise: Natural Product Chemistry, Bioactivity study

I confirm that I have read this submission and believe that I have an appropriate level of expertise to confirm that it is of an acceptable scientific standard, however I have significant reservations, as outlined above.

\section{Author Response 04 Aug 2019}

Swandari Paramita, Mulawarman University, Samarinda, Indonesia

1. The manuscript has sent for proofreading.

2. The plant was authenticated by Ir. Hj. Hastaniah, M.P. and the voucher specimen (voucher number: 27b/UN17.4.3.08/LL/2018) was deposited to Laboratory of Dendrology and Forest Ecology, Faculty of Forestry, Mulawarman University, Samarinda, Indonesia.

3. There was one replication that was conducted in each experiment of every sample. 4. In the discussion has been rewriting to explain the results of the experiments and compare the previous research to support the results.

5. All the species name of the plants has been corrected as "Zingiber montanum" for the first, and "Z. montanum" for subsequent usage.

Competing Interests: No competing interests were disclosed. 
The benefits of publishing with F1000Research:

- Your article is published within days, with no editorial bias

- You can publish traditional articles, null/negative results, case reports, data notes and more

- The peer review process is transparent and collaborative

- Your article is indexed in PubMed after passing peer review

- Dedicated customer support at every stage

For pre-submission enquiries, contact research@f1000.com 